\title{
THE PROS AND CONS OF REDUCTIVE MATTE SMELTING FOR PGMS
}

\author{
R.T. JONES and I.J. GELDENHUYS \\ Pyrometallurgy Division, Mintek, Private Bag X3015, Randburg, 2125, South Africa \\ E-mail: rtjones@global.co.za
}

\begin{abstract}
Platinum group metals (PGMs) are traditionally smelted in electric furnaces where the valuable metals are collected in a base-metal sulphide matte. An alternative to this process is the ConRoast process that uses reductive alloy smelting in a DC arc furnace to collect the valuable metals in an iron-rich alloy. Reductive smelting of feed materials containing PGMs, using carbon as a reducing agent, can be used to obtain high PGM and base-metal recoveries and to ensure the solubility of chromium in slags.

Based on work carried out in Mintek's 3 MW DC arc furnace at throughputs of over 1000 tons per month, it was found that PGMs could be collected effectively, and that the chromium problem could be managed. However, if matte is present in the furnace, there remains a significant risk of furnace failure. Furthermore, the PGM 'lockup' (inventory inside the furnace) in a process that used reductive matte smelting of UG2 concentrates was much greater than that of reductive alloy smelting. Further differences exist in the better working environment and lower emissions of $\mathrm{SO}_{2}$ in the case of the ConRoast process.
\end{abstract}

\section{Keywords}

Pyrometallurgy; extractive metallurgy; precious metal ores; reduction; roasting

\section{INTRODUCTION}

Matte smelting in an electric furnace has been the established route for the treatment of PGM (platinum group metals) ore concentrates since 1969, when the six-in-line furnace took over from the blast furnace. The separation of the base metal sulphides (forming the PGMcontaining matte) from the oxide minerals (which make up the slag) is essentially a simple melting operation. Mostert et al (1973) explained that the reasons for moving away from the blast furnace included the labour-intensive nature of the smelting operation, the rising price of coke, and the introduction of anti-pollution laws that meant that it would be costly to control the emission of a very large volume of gas containing between 1 and 2 per cent sulphur dioxide that resulted from the typical concentrate of that era containing $15 \% \mathrm{Fe}, 6 \%$ $\mathrm{Ni}+\mathrm{Cu}, 8.5-10 \% \mathrm{~S}$, and 110-150 g/t PGMs.

The products of PGM mining today look very different from those of forty years ago, and process changes are required in the smelting of PGM ore concentrates in order to accommodate the increasing amounts of UG2 concentrates that are being produced in the South African Bushveld Complex. These concentrates contain much higher levels of chromium oxides and much lower levels of base metal sulphides than the previously typical concentrates from the Merensky Reef. 
The ConRoast process, previously described by Jones $(2002,2009)$, is an alternative to matte smelting that does not require sulphur to collect the valuable metals, but instead collects the PGMs and base metals in an iron-rich alloy. This proposed solution to the problem of smelting UG2 (and other) concentrates involves roasting of the concentrates to remove most of the sulphur prior to smelting, followed by reductive alloy smelting in a DC arc furnace. This process is unconstrained by the amount of chromium present in the feed, is much environmentally cleaner in terms of sulphur emissions, is much less prone to failure of furnace containment, and achieves very high recoveries of PGMs. The resulting alloy can be treated further either hydrometallurgically, or pyrometallurgically by converting to remove the iron to produce a product very similar to a conventional converter matte.

The challenges facing PGM smelters today can be summarised in terms of three major problems.

\section{The Sulphur Problem}

The emission of $\mathrm{SO}_{2}$ (sulphur dioxide) from furnaces and converters is hard to avoid when using a sulphur-based matte-smelting process. However, the ConRoast process does not rely on the presence of sulphur, as it smelts essentially sulphur-free (or low-sulphur) material in a DC arc furnace and collects the valuable metals in an iron alloy. Sulphur can be removed, prior to smelting, using a fluidized-bed roaster which is a well-enclosed vessel that produces a steady continuous stream of $\mathrm{SO}_{2}$ that can be used for the production of sulphuric acid (if the concentration and scale warrant this course of action). Compared to the traditional mattesmelting process, emissions of $\mathrm{SO}_{2}$ can be orders of magnitude lower if the ConRoast process is used. The capital costs of acid production can also be reduced markedly.

\section{The Chromium Problem}

The traditional matte-smelting process imposes strict limits on the quantity of chromite (prevalent in the UG2 reef) that can be present in the smelter feed, because of the deleterious consequences of build-ups of the very stable crystalline chrome spinel in the furnace. This constraint restricts the recovery of the PGMs in the production of ore concentrates. The ConRoast process eliminates the chromium constraint in smelting and so opens up huge opportunities in the types of materials that can be smelted, and provides an opportunity to significantly enhance the overall process recovery of PGMs (through removing the restrictions in concentrator operations). The essential step in the solution of the chromium problem involves the addition to the furnace of carbon as a reductant, to ensure that the oxidation state of the chromium changes from that of $\mathrm{Cr}_{2} \mathrm{O}_{3}$ to that of $\mathrm{CrO}$, which is readily soluble in the slag.

\section{The Containment Problem}

As the South African platinum producers have moved increasingly to processing ore from the UG2 reef to supplement the previous production from the Merensky reef, there have been numerous furnace failures and explosions in the industry. Increasing smelting temperatures have been used in an attempt to avoid the build-up of chrome spinel emanating from the higher $\mathrm{Cr}_{2} \mathrm{O}_{3}$ contents in UG2 concentrates. Even though water-cooled copper cooling systems have been introduced in recent years, the highly superheated and corrosive molten matte in traditional smelters is inherently difficult to contain. The CEO of one of the major platinum producers was recently quoted by Hasell (2010) as describing the company's largest furnace as "particularly unreliable". On the other hand, the ConRoast process is able to use a simple and robust design of furnace, because the melting temperatures of the slag and alloy are close to each other. 
The two processes briefly described above, namely matte smelting and reductive alloy smelting, are very different from each other, as are the types of furnace in which they are typically carried out. The question has often been asked whether it would make sense to use a hybrid of these two approaches, namely reductive matte smelting, where carbon is used as a reductant, but the product from the furnace remains a sulphide matte. This paper is aimed at answering that question, at least in part.

\section{REDUCTIVE MATTE SMELTING}

Addition of carbon to PGM-containing concentrate in a furnace results in some of the iron (and other metallic) oxides being reduced to the metallic state. To some degree, the chromium oxides from UG2 concentrates will be reduced to $\mathrm{CrO}$, thereby becoming more readily soluble in the slag. These advantages are similar to those enjoyed by the ConRoast process (where sulphur is removed in a fluidized-bed roaster prior to smelting, and the PGMs are collected in an iron-rich alloy), yet there are significant differences between 'reductive matte smelting' and 'reductive alloy smelting'.

Reductive matte smelting is constrained to produce a sulphur-rich matte product, either for reasons of crushability or for compatibility with an existing downstream process. This negates the advantage of the alloy having a high liquidus (melting) temperature that is compatible with that of the slag; and there is considerably higher risk of the super-heated matte penetrating the refractories and breaking out of the furnace.

\section{PILOT-SCALE TESTWORK}

Large-scale demonstration smelting of PGM-containing feed materials has been carried out in Mintek's pilot plant since April 2004. Much of this work involved the processing of revert tailings that had a low sulphur content, as described by Geldenhuys et al (2009). This initial work, carried out in a $1.5 \mathrm{MW}$ DC arc furnace with a shell diameter of $3 \mathrm{~m}$, is used as a reference point for the comparison of more recent furnace campaigns.

The reductive matte-smelting work described here covers two roughly six-month periods of operation of Mintek's 3 MW DC arc furnace, which has a shell diameter of $4.25 \mathrm{~m}$.

It was common practice during the two reductive matte-smelting campaigns to work with a blend of feed materials, typically somewhere around a 75:25 mixture of various highchromium concentrates to converter slag. The converter slag provided a convenient supplementary source of iron for the process, and resulted in an overall slag composition that was acceptable in terms of liquidus temperature and viscosity, and was not overly aggressive. The compositions of the blended feed for each of the campaigns are shown in Table 1. The compositions of the slag and alloy (or matte) products are shown in Tables 2 and 3 . In these tables, the sections marked 'Alloy smelting' refer to the work that was extensively reported on by Geldenhuys et al (2009), where the material smelted over the period May 2004 to August 2008 was revert tailings.

It should be noted that, both for reductive alloy smelting and reductive matte smelting in a DC arc furnace, it is possible to vary the degree of reduction of the iron oxide in the feed to 
metallic iron. The recoveries of the valuable metals are directly linked to the extent to which iron oxide is reduced to the metallic state. Clearly, the mass of the alloy (or matte) that is produced in the furnace is also directly linked to the extent of iron recovery to the alloy. This allows the operator of the furnace significant flexibility to choose the desired operating point, and allows a trade-off to be made between the recovery of the valuable metals and the quantity of alloy that is produced (which then needs to be treated further). In light of this, not too much should be read into the variations between the residual PGM contents of the slags listed below, as these figures simply reflect the operating choices that were preferred (or specified by the client) at the time.

Table 1: Feed composition, mass \% (PGM listed in $\mathrm{g} / \mathrm{t}$ )

\begin{tabular}{|l|c|c|c|c|c|c|c|c|c|c|c|}
\hline & $\mathrm{Al}_{2} \mathrm{O}_{3}$ & $\mathrm{CaO}$ & $\mathrm{Co}$ & $\mathrm{Cr}_{2} \mathrm{O}_{3}$ & $\mathrm{Cu}$ & $\mathrm{FeO}$ & $\mathrm{MgO}$ & $\mathrm{Ni}$ & $\mathrm{S}$ & $\mathrm{SiO}_{2}$ & $\mathrm{PGM} 4 \mathrm{e}$ \\
\hline $\begin{array}{l}\text { Alloy } \\
\text { Smelting }\end{array}$ & 3.73 & 6.42 & 0.14 & 2.41 & 0.30 & 32.2 & 11.79 & 0.89 & 0.76 & 36.2 & 51 \\
\hline $\begin{array}{l}\text { Oct 2008- } \\
\text { Mar 2009 }\end{array}$ & 5.17 & 3.85 & 0.13 & 2.45 & 0.66 & 24.54 & 14.26 & 1.34 & 1.53 & 40.46 & 74 \\
\hline $\begin{array}{l}\text { Oct 2009- } \\
\text { Mar 2010 }\end{array}$ & 3.50 & 2.80 & 0.12 & 2.30 & 0.82 & 20.91 & 18.59 & 1.50 & 1.99 & 40.87 & 167 \\
\hline
\end{tabular}

Note: $\mathrm{PGM} 4 \mathrm{e}=\mathrm{Pt}+\mathrm{Pd}+\mathrm{Rh}+\mathrm{Au}$

Table 2: Slag composition, mass \% (PGM listed in $\mathrm{g} / \mathrm{t}$ )

\begin{tabular}{|l|c|c|c|c|c|c|c|c|c|c|c|}
\hline & $\mathrm{Al}_{2} \mathrm{O}_{3}$ & $\mathrm{CaO}$ & $\mathrm{Co}$ & $\mathrm{Cr}_{2} \mathrm{O}_{3}$ & $\mathrm{Cu}$ & $\mathrm{FeO}$ & $\mathrm{MgO}$ & $\mathrm{Ni}$ & $\mathrm{S}$ & $\mathrm{SiO}_{2}$ & $\mathrm{PGM} \mathrm{4e}$ \\
\hline $\begin{array}{l}\text { Alloy } \\
\text { Smelting }\end{array}$ & 4.41 & 7.27 & 0.05 & 2.83 & 0.09 & 28.7 & 14.06 & 0.11 & 0.34 & 41.3 & 1.12 \\
\hline $\begin{array}{l}\text { Oct2008- } \\
\text { Mar 2009 }\end{array}$ & 6.38 & 4.51 & 0.04 & 3.00 & 0.10 & 18.15 & 17.51 & 0.08 & 0.18 & 48.18 & 0.48 \\
\hline $\begin{array}{l}\text { Oct2009- } \\
\text { Mar 2010 }\end{array}$ & 4.15 & 3.11 & 0.06 & 2.59 & 0.15 & 20.70 & 20.96 & 0.19 & 0.28 & 45.81 & 1.70 \\
\hline
\end{tabular}

Table 3: Alloy composition, mass \% (PGM listed in $\mathrm{g} / \mathrm{t}$ )

\begin{tabular}{|l|c|c|c|c|c|c|c|c|c|}
\hline & $\mathrm{C}$ & $\mathrm{Co}$ & $\mathrm{Cr}$ & $\mathrm{Cu}$ & $\mathrm{Fe}$ & $\mathrm{Ni}$ & $\mathrm{S}$ & $\mathrm{Si}$ & $\mathrm{PGM} 4 \mathrm{e}$ \\
\hline $\begin{array}{l}\text { Alloy } \\
\text { Smelting }\end{array}$ & 0.07 & 1.40 & 0.17 & 3.18 & 77.0 & 10.8 & 6.05 & 0.24 & 662 \\
\hline $\begin{array}{l}\text { Oct 2008- } \\
\text { Mar 2009 }\end{array}$ & 0.05 & 0.94 & 0.46 & 5.56 & 67.18 & 12.26 & 11.42 & 0.18 & 749 \\
\hline $\begin{array}{l}\text { Oct 2009- } \\
\text { Mar 2010 }\end{array}$ & 0.04 & 0.83 & 0.30 & 10.42 & 46.31 & 20.18 & 19.13 & 0.17 & 1968 \\
\hline
\end{tabular}

\section{Campaign 1: October 2008 - March 2009}

The first campaign in the then-new $3 \mathrm{MW}$ furnace at Mintek started out with the intention of doing alloy smelting, as before. However, a serious challenge occurred as a result of feed materials arriving with too high a sulphur content. This resulted in the formation of an alloy with a much lower liquidus temperature than the process is designed to accommodate. The superheated alloy then caused rapid wear of the side-wall refractories, resulting in a leak adjacent to the alloy tap-hole on 27 March 2009. The escaping stream of superheated molten 
alloy cut through one of the cooling circuits, resulting in a series of metal-water explosions just outside the furnace. This incident was well managed and there were no injuries or burns, but it did cause a three-week shutdown of the furnace while repairs were carried out. The incident highlighted the benefits of operating in a low-sulphur alloy-smelting mode, as more than four years of previous incident-free operation were starkly contrasted with a mere six months of operation in high-sulphur mode. This clearly pointed out the limitations of highsulphur feed materials, and the necessity for a full implementation of the ConRoast process including the roasting step. It had been expedient to simply smelt the feed materials directly without first installing a roaster, and this worked quite satisfactorily as long as the sulphur content of the feed was low.

\section{Campaign 2: October 2009 - March 2010}

A second opportunity to try out reductive matte smelting in the $3 \mathrm{MW} \mathrm{DC}$ arc furnace came about almost exactly a year after the first. This time there was a requirement to produce a crushable (rather than granulated) matte product from a range of high-sulphur feed materials.

In order to produce a matte with a close-to-conventional composition, it was necessary to limit the amount of metallic iron that was produced by reduction of iron oxide. This imposed quite a constraint on the operation, as it was also necessary to meet the need for high PGM recoveries.

Because of the ever-present risk of furnace failure caused by super-heated matte, it was prudent to operate the furnace at a lower power intensity (about $60 \%$ ) than was used for the alloy-based ConRoast process. In this case, a target throughput of 1200 tons per month was used, although constraints on the supply of feed material limited actual throughputs to around 1000 tons per month.

The very high sulphur content of the matte resulted in it having a very low liquidus temperature (relative to that of the slag). The superheated matte has a great propensity for penetrating the refractory lining of the furnace. There was a marked difference between the alloy-smelting and matte-smelting operations, in terms of $\mathrm{SO}_{2}$ emissions from the furnace, especially in the immediate working environment during slag and matte tapping.

A notable feature of this campaign is that a significant portion (around a quarter) of the PGMs seemed to stay behind in the furnace. This PGM 'lockup' (inventory inside the furnace) continued to increase for a number of months. At the conclusion of this particular smelting contract, it was required to dig out the furnace contents because of the extensive 'lockup' of the valuable alloy / matte product which was believed to have penetrated the refractory lining including the hearth. This dig-out work is currently underway, but it is very clear from a visual inspection of the furnace that the matte had penetrated the hearth refractory material (normally over one metre thick) almost all of the way to the bottom of the furnace. There was also evidence of matte penetration between refractory bricks in the sidewalls.

\section{Comparison of reductive alloy smelting and reductive matte smelting}

Some highlights of the comparison between the various campaigns are shown in Table 4. Most noteworthy is the increase in the sulphur content of the feed material, from $1.5 \%$ to $2.0 \%$ (compared to much lower average $0.76 \% \mathrm{~S}$ content in the previous four-year alloy- 
smelting series of campaigns). The higher-S feed resulted in alloys containing averages of $11 \%$ and $19 \% \mathrm{~S}$ (and a maximum of $24 \%$ ) for the two reductive matte-smelting campaigns.

Table 4: Summary of main features of the furnace campaigns

\begin{tabular}{|c|c|c|c|}
\hline & Alloy Smelting & Oct 2008 - Mar 2009 & Oct 2009 - Mar 2010 \\
\hline Duration & $\sim 4$ years & 6 months & 6 months \\
\hline Tons smelted & $\sim 37000$ & 6158 & 5793 \\
\hline Highest tons/day & $47.1(=1430 \mathrm{t} / \mathrm{m})$ & $65.8(=2000 \mathrm{t} / \mathrm{m})$ & $47.2(=1440 \mathrm{t} / \mathrm{m})$ \\
\hline $\begin{array}{l}\text { Mass of Alloy / Mass } \\
\text { of Feed, } \%\end{array}$ & 7.3 & 10.0 & 6.5 \\
\hline $\begin{array}{l}\text { Mass of Slag / Mass of } \\
\text { Feed, \% }\end{array}$ & 84 & 82.0 & 94.2 \\
\hline$\% \mathrm{~S}$ in feed & 0.76 & 1.53 & 1.99 \\
\hline$\% \mathrm{~S}$ in alloy, average & 6.1 & 11.4 & 19.1 \\
\hline$\% \mathrm{~S}$ in alloy, maximum & N/A & 15.6 & 23.9 \\
\hline$\% \mathrm{Cr}_{2} \mathrm{O}_{3}$ in feed & 2.4 & 2.5 & 2.3 \\
\hline $\begin{array}{l}\text { Mass Cr in alloy / } \\
\text { Mass of Cr in feed, \% }\end{array}$ & $0.5-1.4$ & 2.8 & 1.2 \\
\hline $\begin{array}{l}\text { PGM recovery, \% } \\
\text { Alloy / (Alloy + Slag) }\end{array}$ & 99 & 99 & 99 \\
\hline $\begin{array}{l}\text { PGM retention in } \\
\text { furnace }= \\
1-((\text { Alloy }+ \text { Slag }) / \text { Feed })\end{array}$ & $\begin{array}{l}\text { Not directly comparable } \\
\text { with other two campaigns }\end{array}$ & $-2 \%$ & $23 \%$ \\
\hline Furnace integrity & $\begin{array}{l}\text { No failures in four } \\
\text { years of operation }\end{array}$ & $\begin{array}{c}\text { Tap-hole leak after six } \\
\text { months }\end{array}$ & $\begin{array}{l}\text { No failure, but } \\
\text { extensive matte } \\
\text { penetration of } \\
\text { refractories }\end{array}$ \\
\hline Corrosion of steelwork & $\begin{array}{l}\text { No significant } \\
\text { corrosion }\end{array}$ & Off-gas area & $\begin{array}{l}\text { Corroded upper side- } \\
\text { walls and off-gas area }\end{array}$ \\
\hline $\begin{array}{l}\mathrm{SO}_{2} \text { emissions from } \\
\text { furnace }\end{array}$ & Very low & Significant & High \\
\hline
\end{tabular}

\section{CONCLUSIONS}

Testwork at Mintek has shown that reductive matte smelting in a DC arc furnace is able to accommodate the smelting of high-chromium feed materials by means of using carbon as a reductant to ensure the solubilisation of chromium oxide in the slag. However, because of the high sulphur content of the feed materials to the furnace, the major challenges of furnace integrity and sulphur emissions remain, using this approach.

The use of a smelting approach that is a hybrid of matte smelting and reductive alloy smelting is akin to the idea of trying to 'cross a chasm using small steps'. It is better to choose which side of the chasm you would like to be on and then to fully embrace all aspects of that option.

The preferred solution to the problem of smelting UG2 concentrates involves roasting of the concentrates to remove most of the sulphur prior to smelting, followed by reductive alloy smelting in a DC arc furnace. This process is unconstrained by the amount of chromium present in the feed, is much environmentally cleaner in terms of sulphur emissions, is much less prone to failure of furnace containment, and achieves very high recoveries of PGMs. 
The resulting alloy can be treated further either hydrometallurgically, or pyrometallurgically by converting to remove the iron to produce a product very similar to a conventional converter matte.

\section{ACKNOWLEDGEMENTS}

This paper is published by permission of Mintek. The assistance of many colleagues at Mintek, in particular Tom Curr, Glen Denton and Cornel Potgieter, is gratefully acknowledged.

\section{REFERENCES}

Geldenhuys, I.J. and Jones, R.T., Four years of DC arc smelting of PGM-containing oxide feed materials at Mintek, In Nickel and Cobalt 2009: Advances in the Processing of Nickel, Cobalt and PGMs using Pyrometallurgical Techniques, 48th Annual Conference of Metallurgists, Sudbury, Ontario, Canada, 23-26 August 2009, pp.415-427. http://www.mintek.co.za/Pyromet/Files/2009Geldenhuys.pdf

Hasell, N., Molten metal too hot to handle, Quotation by Farmer, I. Times Online, 11 May 2010.

http://business.timesonline.co.uk/tol/business/markets/article7122317.ece

Jones, R.T., ConRoast: DC arc smelting of dead-roasted sulphide concentrates, In Third International Sulfide Smelting Symposium (Sulfide Smelting '02), R.L. Stephens and H.Y. Sohn (Eds.), TMS (The Minerals, Metals, \& Materials Society), Seattle, Washington, USA, 17-21 February 2002, TMS Annual Meeting, pp.435-456.

http://www.mintek.co.za/Pyromet/Files/ConRoast.pdf

Jones, R.T., Towards commercialisation of Mintek's ConRoast process for platinum smelting. In Nickel and Cobalt 2009: Advances in the Processing of Nickel, Cobalt and PGMs using Pyrometallurgical Techniques, 48th Annual Conference of Metallurgists, Sudbury, Ontario, Canada, 23-26 August 2009, pp.159-168. http://www.mintek.co.za/Pyromet/Files/2009Jones-ConRoast.pdf

Mostert, J.C. and Roberts, P.N., Electric smelting at Rustenburg Platinum Mines Limited of nickel-copper concentrates containing platinum-group metals. SAIMM Journal, 1973, 73(9), 290-299.

http://www.saimm.co.za/Journal/v073n09p290.pdf 